\title{
Assessing the distribution and changes of instream woody habitat in south- eastern Australian rivers
}

Zeb Tonkin ${ }^{1}$, Adrian Kitchingman ${ }^{1}$, Renae M. Ayres ${ }^{1}$, $\operatorname{Jarod~Lyon~}^{1}$, Ian D.

Rutherfurd $^{2}$, Justin C.Stout ${ }^{2}$, Paul Wilson ${ }^{3}$

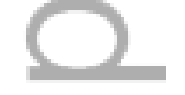

${ }^{1}$ Arthur Rylah Institute for Environmental Research. Department of Environment,

Land, Water and Planning, Heidelberg, Victoria, 3084, Australia.

${ }^{2}$ The University of Melbourne. School of Geography, Parkville, Victoria, 3010,

Australia.

${ }^{3}$ Water and Catchments. Department of Environment, Land, Water and Planning,

East Melbourne, Victoria, 3002, Australia.

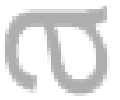

*Corresponding author:

Zeb Tonkin

Arthur Rylah Institute for Environmental Research, Department of Environment,

Land, Water and Planning, 123 Brown Street, Heidelberg, Victoria, 3084, Australia

Email: zeb.tonkin@delwp.vic.gov.au

Telephone: +61394508660

Fax: +61394508799

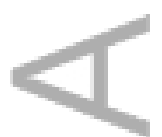

Short title: Assessing instream woody habitat distribution and change

This is the author manuscript accepted for publication and has undergone full peer review but has not been through the copyediting, typesetting, pagination and proofreading process, which may lead to differences between this version and the Version of Record. Please cite this article as doi: $10.1002 /$ rra.3002

This article is protected by copyright. All rights reserved. 
Keywords: Large woody debris; Restoration; Management; Desnagging; Reference reaches; Condition; Riverscape

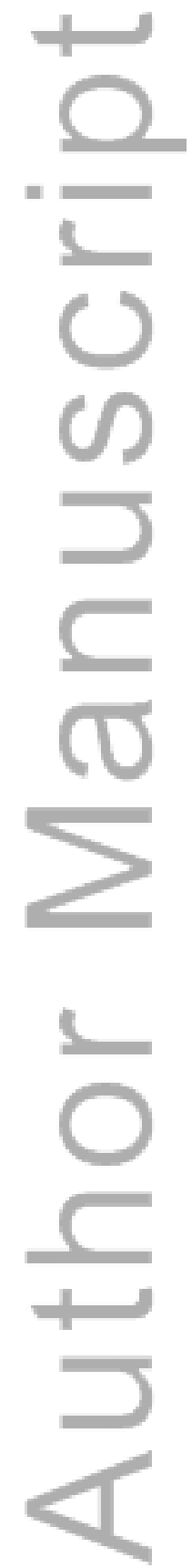

This article is protected by copyright. All rights reserved. 


\begin{abstract}
Managers and communities are now artificially reintroducing instream woody habitat (IWH) to rivers following historic large scale removal. Riverscape scale datasets that quantify existing habitat conditions are fundamental to setting the priorities and allocating resources for such programs. Unfortunately, such datasets are rare, primarily because existing assessment approaches are limited in their accuracy (remote sensing) or are costly and labour intensive (field assessments). This study used both field assessments and aerial data to improve the accuracy of remotely sensed measures of IWH and estimate current IWH volumes and subsequent condition (compared to reference levels) across approximately $28,000 \mathrm{~km}$ of stream in the south eastern Australian state of Victoria.
\end{abstract}

We found that aerial measures, when used in conjunction with measures of stream size and riparian overhang, produced significantly better estimates of IWH loads than using aerial data alone. The state-wide assessment indicated streams currently have IWH volumes, on average, $41 \%$ lower than reference levels which represented an average reduction of $0.0207 \mathrm{~m}^{3} \mathrm{~m}^{-2}$. The degree of IWH condition was highly variable across regions (20\% - 95\% reductions from reference levels); a likely reflection of regional variation in land use practices and past river works activities.

This scale of IWH reduction may pose major negative impacts on the ecological integrity of these streams. Whilst the approach used during this study has temporal and spatial limitations, it was designed as a generalised, rapid and relatively 
inexpensive method to measure stream condition and assist with priority setting at state and regional levels.

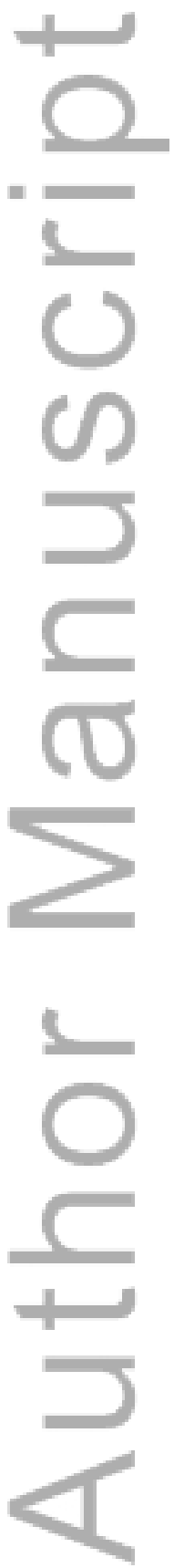

This article is protected by copyright. All rights reserved. 


\section{Introduction}

The presence of in-stream wood directly influences the geomorphology and ecology of a river through the interactions of wood with flow and sediment. Of particular importance to the aquatic assemblages found in most rivers is the role of instream wood in the provision of habitat. Instream wood influences local and reach scale hydraulics, and can assist in the development and diversity of channel habitat units such as pools and riffles, secondary channels, and changes in bed sediment grainsize (Mosley, 1981; Gippel et al., 1996; Rosenfeld and Huato, 2003; Borg et al., 2007; Mao et al., 2008; Eaton et al., 2012). These geomorphic consequences, along with the in-stream wood itself, influence primary production and community composition, particularly by providing essential physical habitat for biofilms, invertebrates and fish (Benke et al., 1985; Wallace et al., 1995; Crook and Robertson, 1999; Brooks et al., 2004; Nicol et al., 2004; Gurnell et al., 2005). As such, we refer to instream wood as instream woody habitat (IWH) to convey its ecological importance and need for its preservation, rather than use terms such as "woody debris" which can have negative connotations (e.g. Koehn et al., 2004; Kitchingman et al., 2013).

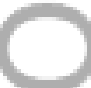

Traditional perceptions of the negative consequences of instream wood on flooding, navigation and erosion, led to extensive riparian clearing and direct removal of large quantities of IWH in rivers internationally (Abbe and Montgomery, 1996; Gippel et al., 1996; Brooks et al., 2004; Chin et al., 2014). Such reductions in IWH have contributed to declines in the productivity and diversity of aquatic ecosystems (Crook and Robertson, 1999; Maddock, 1999; Brooks et al., 2004). Importantly, research 
demonstrating the positive role of IWH has led to an upsurge in IWH restoration, indirectly through the revegetation of riparian zones (to provide longer term wood inputs) and directly via wood reintroduction. The goal is to simulate natural conditions, encourage natural geomorphic processes, and reverse measured declines in diversity and abundance of aquatic organisms (Borg et al., 2007; Máčka et al., 2011). These activities have moved from small local projects, to consideration of wood at a riverscape scale (Ormerod, 2004; Gilvear et al., 2012). There is therefore a need to understand the (dis)connectivity of river systems and associated IWH patterns across riverscapes (Fryirs and Brierly, 2007; Baillie et al., 2008). A key element of achieving such an understanding is the collection and interpretation of reliable landscape-scale habitat data, which are fundamental to the setting of priorities and the allocation of resources by state and regional managers (Ladson et al., 1999; Kaeser and Litts, 2012). Marcus and Fonstad (2008) illustrate that at the riverscape scale, our understanding of river form, process and function is largely based on locally intensive mapping of river reaches, or on spatially extensive, but low density, data scattered throughout a riverscape. Indeed, this is true for IWH, with few examples of assessments conducted over a range of stream sizes and across large catchments using consistent sampling methods (Baillie et al., 2008). This is primarily because the most common methods for describing IWH, based on detailed measures such as volume, are difficult and costly to apply over large spatial scales (Marcus et al., 2002; Kaeser and Litts, 2012; Atha and Dietrich, 2015). 
Recent advances in optical remote sensing of rivers make it easier to generate accurate and continuous maps of in-stream attributes, including IWH, at sub-meter resolutions across entire watersheds (Marcus and Fonstad, 2008). Unfortunately, the quality of IWH data generated from aerial imagery is constrained by stream overhang, shading from riparian vegetation, and water clarity (e.g. Marcus et al., 2002; Marcus and Fonstad, 2008). Alternatively (or complementarily), Kitchingman et al., (2013) presented a new assessment procedure which incorporates a rapid on ground field survey method to map IWH densities. Their approach has since been applied to predict pre-disturbance (reference) IWH conditions across riverscapes (Kitchingman et al., 2015), and to identify IWH units (no. pieces, complexity and volume) as part of an increasing government investment into assessing waterway health across the southeastern Australian state of Victoria (Wilson, 2013).

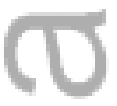

This study builds on earlier work by Kitchingman et al., (2015) that used field measures of IWH loads in reference reaches to develop a statistical model that could estimate the reference wood load for all major streams in the state of Victoria, southeastern Australia (28,000 km of stream). We compare the reference IWH loads from Kitchingman et al., (2015) with the existing IWH loads in this same stream network to make an assessment of the present IWH condition. This is, to our knowledge, the most spatially extensive mapping exercise of IWH (globally) to date.

Our study has two main components. Firstly, we determined existing IWH loads using aerial photographs. We accounted for the likely underestimate of IWH using 
aerial derived IWH data (due to IWH hidden under overhanging vegetation and submerged under turbid water) by undertaking a series of on-ground IWH assessments to compare and calibrate measures derived from aerial photography alone. This calibration was applied to the census derived from the full aerial photograph set for the state (Wilson, 2013). Secondly, we compared our estimates of existing IWH loads with predictions of reference IWH volumes reported by Kitchingman et al., (2015) to assess the current condition of IWH across the stream network. We hypothesised that current volumes of IWH would be considerably lower than predictions of reference conditions, and that such reductions would vary across regions.<smiles>C1CC1</smiles>
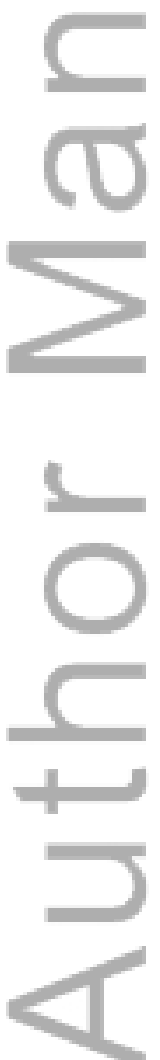

This article is protected by copyright. All rights reserved. 


\section{METHODS}

\section{Study area}

The state of Victoria, located in south eastern Australia, covers approximately $227,600 \mathrm{~km}^{2}$, encompassing watercourses exhibiting considerable variation in the geomorphology, hydrology and subsequent flora and fauna (VRHS, 2002;

Kitchingman et al., 2015). Victoria has been divided into 19 distinct 'Riverine Biological Regions' according to characteristics which influence or are the product of riverine aquatic habitats (VRHS, 2002). Approximately 1,500 'reaches' across $28,000 \mathrm{~km}$ of Victoria's Index of Stream Condition (ISC) network provided a broad framework to compare and assess various values and uses of rivers (Ladson et al., 1999). For the purposes of this study, ISC reaches have been further divided into 38,988 stream 'links' (mean length $754 \mathrm{~m}$ ), which form a fine-scale stream network, populated with a suite of physiographic, bioclimatic, edaphic and land-cover variables (see Chee and Elith, 2012).

\section{Aerial derived IWH data}

We used geo-referenced aerial photography (15 cm GSD +/- 3 pixels accuracy) and light detection and ranging (LIDAR) data of the entire Victorian ISC network undertaken during summer low flow periods during 2009, 2010 or 2011 (dependant on site specific hydrology). This full coverage of the ISC network has been used for a variety of catchment management reporting including measures of riparian health, bank condition and IWH (Wilson, 2013). 
We used the statewide dataset of aerial photography derived IWH masses to create estimates of standardised wood volumes $\left(\mathrm{m}^{3} \mathrm{~m}^{-2}\right)$ for each of the stream links of the Victorian ISC network. The data set comprised of geolocated IWH masses, including their corresponding measures of size (footprint area $\left(\mathrm{m}^{2}\right)$ ) and complexity (number of contiguous pieces / large branches) (Figure 2). This enabled direct comparisons with on-ground assessments undertaken in this and recent studies (Kitchingman et al., 2013). We estimated overhanging vegetation cover (\%) for each stream link using the LIDAR data set of the ISC network.

\section{On-ground IWH assessments}

On-ground IWH assessments were used to scrutinize the precision of data obtained from aerial photography. On-ground assessments included those conducted as part of the state-wide investigation of reference IWH distributions from 186 stream links (combined $83 \mathrm{~km}$ in length; see Kitchingman et al., 2015) along with IWH assessments of a further 391 stream links (combined $305 \mathrm{~km}$ in length) of varying stream sizes, altitudes and riparian condition across the state. This resulted in the collation of high accuracy IWH data from a total of 477 stream links within the Victorian ISC stream network.

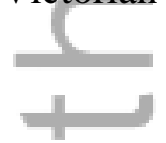

On-ground IWH assessments of stream links were undertaken between December 2011 - October 2012 during periods of stable low flows which were similar to the conditions of aerial imagery capture. Assessments were conducted following methods described in Kitchingman et al. $(2013 ; 2015)$. Briefly, IWH were defined as parts of 
dead trees, shrubs or masses thereof, with a minimum diameter of $0.1 \mathrm{~m}$ and length of $1 \mathrm{~m}$, that were continually exposed to the operation of hydrogeomorphological processes (Gippel, Finlayson and O'Neill, 1996; Máčka, et al., 2011). The location of each IWH mass, along with its estimated size and complexity were recorded using a Trimble ${ }^{\circledR}$ GeoExplorer ${ }^{\circledR}$ XT6000 series handheld Global Navigation Satellite System coupled with a laser range finder. A Hummingbird ${ }^{\circledR}$ 998c SI side imaging sonar system was employed at boat sites to help identify submerged IWH. Both size and complexity parameters were categorised into one of four categories, producing 16 possible combinations of size and complexity for any given IWH mass.

\section{Analysis}

Raw data was processed using ESRI ${ }^{\circledR}$ ArcMap $^{\text {TM }} 10.0$ GIS software. The aerial and on-ground assessment datasets were filtered to only include IWH masses within the toe-of-bank line, given this is the area most exposed to hydrogeomorpological processes and subsequent provision of habitat to aquatic fauna. Individual IWH masses within both datasets were then assigned into one of 16 categories (based on size-complexity scores) and corresponding volume estimates as presented by Kitchingman et al., (2015; Table 1). The total IWH volume calculations for each stream link were then divided by the links toe-of bank area (most representative of the wetted surface area) to produce a standardised wood volume $\left(\mathrm{m}^{3} \mathrm{~m}^{-2}\right)$, which is comparable to units reported in international literature (Hooke, 2007; Pesonen et al., 2008) and recommended by Wohl et al., (2010). Both sets of standardised wood volume estimates (generated from field-tested and aerial data sets respectively) were 
then used to calibrate the aerial census data, and then to estimate IWH wood loads across the state.

\section{Calibrating aerial IWH data}

On-ground estimates of IWH volumes were used to assess the accuracy of aerially derived data. A generalized linear modelling (GLM) approach (using a gaussian distribution and logarithmic link function) was used to determine whether aerial data and measures of riparian overhang (\% overhang) and stream size (mean bankwidth) generate more accurate estimates of IWH volumes than aerial estimates alone. The relative support for each of these models was assessed by calculating Akaike's Information Criterion (AIC), corrected for small sample size (AICc) (Burnham and Anderson, 1998). AICc values were rescaled as differences between that model and the model with the lowest AICc value. A prediction error was calculated using a Kfold cross validation with adjustment against bias ( $\mathrm{R}$ cross-validation for Generalized Linear Models; R Development Core Team, 2013). To test the model's relevance the same approach was performed using only the aerial data as a predictor. We generated $\mathrm{R}^{2}$ values of the two models to gauge any scale of improvement. The resulting best fitting model was then used to predict current IWH volumes for each of the 38,988 stream links.

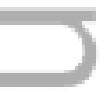

II. Assessing current IWH loads across Victoria

To assess the current IWH load for individual stream links, current volumes were compared to the predicted reference values as reported by Kitchingman et al., (2015) 
using a paired t-test. A standardised condition value for each stream link, reported as the proportional change in IWH was produced by dividing the current IWH volume by its reference volume. A Kruskal-Wallis test was applied to identify whether there were differences in IWH condition values across the 19 river regions of Victoria (VRHS, 2002).

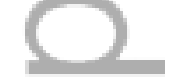

푸

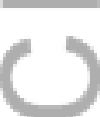

$\infty$
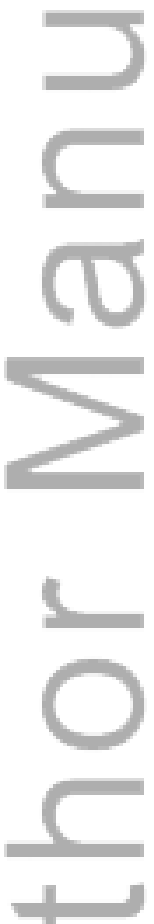

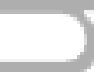

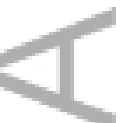

This article is protected by copyright. All rights reserved. 


\section{RESULTS}

\section{Calibrating aerial IWH data}

Aerially derived estimates of IWH volumes were generally below the volumes generated by on-ground assessments. Volumes were increasNorth eastingly underestimated as the proportion of stream link area covered by vegetation overhang increased (Figure 3). Accordingly, the estimates of IWH volumes were tested using all interactions of aerial IWH volumes, vegetation overhang and bank width, with the best fitting model (model 1) having all main effects and aerial IWH volume two way interactions (Table 2). Using a 10 fold GLM cross-validation, the model prediction error was $0.00202 \mathrm{~m}^{3} \mathrm{~m}^{-2}$ with a percentage error of $2.4 \%$. The final model, model 1 explained $42 \%$ of the variance (adjusted $\mathrm{R}^{2}$ ) compared to $15 \%$ when only aerial IWH volumes were used.

\section{State-wide assessment of current IWH volumes}

Model 1 was used to estimate current volumes of IWH for each of the 38,988 stream links of the Victoria's ISC network (Figure 4). The average current volume of IWH throughout Victorian rivers was predicted to be $0.0128 \mathrm{~m}^{3} \mathrm{~m}^{-2}$ with average volumes varying both within and across river regions (Figure 4; Table 3).

Comparisons between predicted current and reference IWH volumes (as presented by Kitchingman et al., 2015) indicated major reductions in IWH across Victoria (Figure 5; Table 3). Current IWH volumes were substantially lower than reference loads, 
being on average $0.0207 \mathrm{~m}^{3} \mathrm{~m}^{-2}$ below the state-wide average predicted level of $0.0336 \mathrm{~m}^{3} \mathrm{~m}^{-2}(\mathrm{t}=170.16, \mathrm{df}=38,931, \mathrm{p}<0.001)$.

Condition values (which is defined as \% change from reference predictions) represented an average reduction in IWH of approximately $41 \%$ (Table 3 ). All river regions displayed a median negative condition value, indicating all regions were below predicted reference IWH levels. There was a significant difference in condition values across regions (Kruskal-Wallis, $\mathrm{p}<0.001$ ), with a general trend of river regions in western Victoria being in poorer IWH condition (higher \% change) than more eastern river regions (Figure 5; Table 3). The South west floodplains, the Glenelg and South Central river regions, displayed the greatest percentage change and were predicted to be in poorest IWH condition (median reductions of $95 \%, 86 \%$ and $80 \%$ respectively). In comparison, the North east uplands, East Gippsland uplands and Alps were predicted to be in the best condition because they showed the smallest percentage change $(20 \%, 23 \%$ and $37 \%$ reductions respectively). Indeed, our results follow a general trend of IWH condition being greatest in headwater streams (usually found within state- and national parks).

This article is protected by copyright. All rights reserved. 


\section{DISCUSSION}

This study presented a consistent approach to measuring instream woody habitat volumes across catchments. Predictions of current IWH volumes, and comparisons with reference levels (as predicted by Kitchingman et al., 2015), provide a quantitative assessment of the current condition of IWH across a large spatial scale. There are few examples of IWH assessments conducted across riverscapes (Baillie et al.,2008; Atha and Dietrich, 2015), despite the global recognition of the importance of instream wood in shaping river health and subsequent upsurge in restoration programs (Borg et al., 2007; Máčka et al., 2011).

Our study revealed that IWH volumes across Victoria are on average $41 \%$ lower than reference levels. This represented an average reduction of $0.0207 \mathrm{~m}^{3} \mathrm{~m}^{-2}$ in IWH. Whilst it is well established that large expanses of Australian rivers and streams have reduced levels of IWH (Gippel et al., 1996; Erskine and Webb, 2003; Brooks et al., 2004), there has been little information available which quantifies such reductions to help guide wood reintroduction programs (e.g. Nicol et al., 2004). The results of our study estimate the volumes of IWH needed to restore to near-reference conditions.

Of course, targets of IWH restoration, whether it be through direct IWH reintroductions or natural processes following riparian revegetation, will also be dependent on resource availability, ecological objectives and other constraints related to infrastructure risk and flooding. 
We also found spatial differences in IWH condition across Victoria's riverine biological regions. For example, IWH volumes in the South west floodplain region were found to be $95 \%$ below reference condition, as compared to the North East uplands region which displayed median reductions of $20 \%$. The varying condition of IWH across river regions primarily reflects varying land use practices and past river works activities, such as wood removal and bank stabilisation, as indicated by historical works records (DOWR, 1989). Within region variation in IWH condition in south eastern Australia has been demonstrated by Brooks et al., (2003). They found that differences in IWH volumes and the geomorphology between two rivers in the East Gippsland region resulted from varying levels of wood removal and riparian clearing.

It is interesting to note that formal government sponsored wood removal has not been widespread in western Victoria (DOWR, 1989), so the low present IWH load in these western streams requires explanation. We propose that these numbers could be explained by informal removal of wood from streams by adjacent landholders; and by low levels of IWH recruitment back into the stream because of extensive removal of riparian vegetation, and the slower rate at which wood enters the stream in this region. The ISC data indicate the streams throughout western Victoria have lost much more of their riparian vegetation than in other regions of the state (Wilson, 2013), indicative of a reduction in the amount of IWH available to recruit back into the system. In addition, regional specific climatic and geomorphic processes that affect the rate of IWH recruitment, such as bank erosion rates and stream power, are also likely to 
contribute to the regional variability of IWH condition (Nicol et al, 2002; Benda and Sias, 2003). Indeed, western Victorian streams are also likely to exhibit low recruitment rates of IWH due to the low stream power and erosion rates (as interpreted by low rainfall and stream gradients) in the region.

The large scale of reductions in IWH loads documented in this study suggests that IWH loss is likley to have had major negative impacts on the ecological health of south eastern Australian streams. IWH plays a vital role in shaping the ecology of many streams as demonstrated by direct links between biofilms, invertebrates and fish (Benke et al., 1985; Wallace et al., 1995; Brooks et al., 2004; Gurnell et al., 2005). For example, fish communities within the Murray-Darling Basin, Australia, have been estimated to represent approximately 10 per cent of pre-European levels, with habitat degradation thought to be a major contributing factor (Lintermans, 2007). Current conditions of IWH are likely to continue to impact remaining ecological communities, particularly when also exposed to climate change threats of increased severity and frequency of drought across south eastern Australia (Balcome et al., 2011;

Morrongiello et al., 2011). Several studies have demonstrated that rivers exposed to IWH and riparian removal, shift to a more homogenised bed profile, thus reducing the frequency and depth of pools (Wallace et al., 1995; Brooks et al., 2003). Pool habitats provide vital refugia for aquatic fauna during periods of low flow (Hermoso et al., 2013). Therefore streams which have undergone major reductions in IWH, are also likely to be less resilient to any increases in environmental extremeties, such as drought. Of course, testing the ecological consequences of changes in IWH 
distribution is still required. Our resultstherefore provide opportunity to further investigate links between IWH distribution, condition and ecological indices (e.g. fish occupancy).

As predicted, stream reaches with greater proportions of riparian overhang increased the errors associated with aerial measures of IWH, which is recognised as a major limiting factor of aerial data sets (Marcus et al., 2002; Marcus and Fonstad, 2008). The modelling approach applied in this study greatly improved the accuracy of aerial IWH measures $\left(\mathrm{R}^{2}=0.42\right.$ compared to 0.15$)$ by incorporating values of riparian overhang and stream size. Whilst the final predictions of IWH volumes are not without error (as are all model predictions), such errors may be viewed as negligible if used to identify stream reaches in poor condition, given reaches with low riparian overhang $(<75 \%)$ have greater model accuracy and more likely to be in poorer condition (due to low IWH recruitment). Furthermore, the aerial, remote sensing approach overcomes costly and labour intensive on ground surveys, particularly if applied over broad spatial scales (see Marcus et al., 2002; Kaeser and Litts, 2012; Atha and Dietrich, 2015).

We also acknowledge the uncertainties of this study beyond measurement error which should be considered during interpretation. Most notably, our assessment of condition, using observed / expected data, is largely governed by the reference wood load predictions of Kitchingman et al., (2015). Whilst the authors of this study have outlined a variety of limitations which should be considered when interpreting these 
estimates, it is important to highlight that any variation in estimated volumes of IWH under reference condition will change any associated condition score. For example, Kitchingman et al., (2015) suggests predictions of pre-European IWH loads in ephemeral stream reaches may be over-estimated due to higher rates of wood decomposition. This effect may explain some of the large modelled decline in wood loads in the west of the state as these streams have proportionally more ephemeral streams (Robson, 2008).

Care should also be taken when interpreting predictions of IWH loads of reaches with variables outside of those used to generate the predictive models. For example, we surveyed very few river reaches greater than $80 \mathrm{~m}$ in width or subject to tidal influences, thus predictions for such reaches should be treated with caution. Given the assessment is lacking any temporal repetition, the results may quickly become redundant for reaches with high rates of IWH recruitment and movement (such as those with high stream power; e.g. Atha and Dietrich, 2015) or those which have experienced events known to influence IWH loads such as bushfire, flooding and severe storms (Young, 1994; Daniels, 2006). River reaches with high stream power and / or healthy riparian zones, however, are generally not targeted for restoration works, thus, temporal variation in data will be of less concern if used to inform further investment such as wood reintroduction.

Kitchingman et al., (2013) designed this IWH assessment approach as a generalised method to support broad scale management decisions. Whilst this approach is suitable 
to broadly identify areas for IWH restoration, we recommend that further investment at smaller spatial scales is needed to provide detailed site based information. For example, if a reach is in poor condition and requires restoration, it should undergo a more detailed on-ground assessment of IWH, with consideration of other factors which may influence management objectives including site access, ecological value, public support, funding, resources and likelihood of success of the intervention. Furthermore, during the prioritization process, a site specific assessment should be undertaken to determine the probability of reaches autonomously recovering a sufficient load of IWH. These assessments should be based on the physical processes that deliver and remove wood from that reach, and if an adequate source of wood is available for recruitment.

The ability to assess IWH volumes and subsequent condition across riverscapes, as presented in this study, enables waterway managers to report on stream condition, assist with priority setting, judge the long-term effectiveness of rehabilitation programs and assist with adaptive management at state and regional levels (Ladson et al., 1999; Kaeser and Litts, 2012). We demonstrated that south eastern Australian streams have undergone dramatic reductions in IWH, which is likely to subsequently effect the ecological integrity of these waterways. Our findings endorse the already large investments in stream restoration programs and provide an opportunity to test the ecological consequences of changes in IWH distribution.

\section{Acknowledgements}

This article is protected by copyright. All rights reserved. 
We thank the many people who contributed to this project. In particular, Justin O’Mahony, Joanne Kearns, Graeme Hackett, Scott Raymond, Jason Lieschke and Mike Nicol assisted in the collection of field data; Paul Maloney and Nick Bond for biometric support; and Matt Bruce for his helpful review of the manuscript. This work was funded by the Natural Resources and Water Sector groups of the Department of Environment and Primary Industries, Victoria.

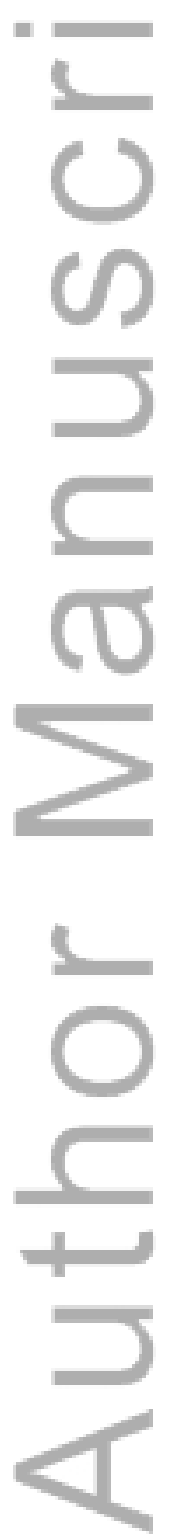

This article is protected by copyright. All rights reserved. 


\section{References}

Abbe TB, Montgomery DR. 1996. Large woody debris jams, channel hydraulics and habitat formation in large rivers. Regulated Rivers: Research \& Management 12: 201221.

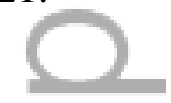

Atha JB, Dietrich JT. 2015. Detecting Fluvial Wood in Forested Watersheds using LiDAR Data: A Methodological Assessment. River Research and Applications: Early view DOI 10.1002/rra.2989.

Baillie BR, Garrett LG, Evanson AW. 2008. Spatial distribution and influence of large woody debris in an old-growth forest river system, New Zealand. Forest Ecology and Management 256: 8.

Balcombe SR, Sheldon F, Capon SJ, Bond NR, Hadwen WL, Marsh N, Bernays SJ. 2011. Climate-change threats to native fish in degraded rivers and floodplains of the Murray-Darling Basin, Australia. Marine and Freshwater Research 62: 1099-1114.

Benda LE, Sias JC. 2003. A quantitative framework for evaluating the mass balance of in-stream organic debris. Forest Ecology and Management 172(1): 1-16.

Benke AC, Henry RL, Gillespie DM, Hunter RJ. 1985. Importance of Snag Habitat for Animal Production in Southeastern Streams. Fisheries 10: 8-13. 
Borg D, Rutherfurd I, Stewardson M. 2007. The geomorphic and ecological effectiveness of habitat rehabilitation works: Continuous measurement of scour and fill around large logs in sand-bed streams. Geomorphology 89: 205-216.

Brooks AP, Brierley GJ, Millar RG. 2003. The long-term control of vegetation and woody debris on channel and flood-plain evolution: insights from a paired catchment study in southeastern Australia. Geomorphology 51:7-29.

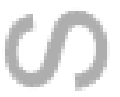

Brooks AP, Gehrke PC, Jansen JD, Abbe TB. 2004. Experimental reintroduction of woody debris on the Williams River, NSW: geomorphic and ecological responses. River Research and Applications 20: 513-536.

Burnham KP, Anderson DR. 1998. Model Selection and Inference: A Practical Information-Theoretic Approach. Springer-Verlag: New York, NY, USA.

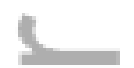

Chee YE, Elith J. 2012. Spatial data for modelling and management of freshwater ecosystems. International Journal of Geographical Information Science 26: 2123 2140.

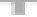

Chin A, Laurencio LR, Daniels MD, Wohl E, Urban MA, Boyer KL, Butt A, Piegay H, Gregory KJ. 2014. The significance of perceptions and feedbacks for effectively managing wood in rivers. River Research and Applications 30: 98-111. 
Crook DA, Robertson AI. 1999. Relationships between riverine fish and woody debris: implications for lowland rivers. Marine and Freshwater Research 50: 941953.

Daniels M.2006. Distribution and dynamics of large woody debris and organic matter in a low-energy meandering stream. Geomorphology 77 (3): 286-298.

DOWR. 1989. Water Victoria: an environmental handbook. VGPO on behalf of the Department of Water Resources: Melbourne, Victoria, Australia.

Eaton BC, Hassan MA, Davidson SL. 2012. Modelling wood dynamics, jam formation, and sediment storage in a gravel-bed stream. Journal of Geophysical Research: Earth Surface 117(F4). DOI:10.1029/2012JF002385.

Erskine WD , Webb AA. 2003. Desnagging to resnagging: new directions in river rehabilitation in southeastern Australia. River Research and Applications 19: 233-249.

Fryirs KA, Brierly GJ. 2007. Buffers, barriers, and blankets: The (dis)connectivity of catehment-scale sediment cascades. Catena 70(1): 45-67.

This article is protected by copyright. All rights reserved. 
Gilvear DJ, Casas-Mulet R, Spray, CJ. 2012. Trends and issues in delivery of integrated catchment scale river restoration: Lessons learned from a national river restoration survey within Scotland. River Research and Applications 28: 234-246.

Gippel CJ, Finlayson BL, O'Neill IC. 1996. Distribution and hydraulic significance of large woody debris in a lowland Australian river. Hydrobiologia 318(3): 179-194.

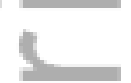

Gurnell A, Tockner K, Edwards P, Petts, G. 2005. Effects of deposited wood on biocomplexity of river corridors. Frontiers in Ecology and the Environment 3: 377382.

Hermoso V, Ward DP, Kennard MJ. 2013. Prioritizing refugia for freshwater biodiversity conservation in highly seasonal ecosystems. Diversity and Distributions 19: $1031-1042$.

Hooke JM. 2007. Spatial variability, mechanisms and propagation of change in an active meandering river. Geomorphology 84: 277-296.

Kaeser AJ, Litts TL. 2012. A novel technique for mapping habitat in navigable streams using low-cost side scan sonar. Fisheries 35: 163-174.

This article is protected by copyright. All rights reserved. 
Kitchingman A, Tonkin Z, Lyon J. 2013. A novel approach to spatially assessing instream woody habitat densities across large areas. Journal of Environmental Management 128: 555-560.

Kitchningman A, Tonkin Z, Ayres RM, Lyon J, Stout JC, Rutherfurd ID, Wilson P. 2015. Predicting natural instream woody-habitat loads across large river networks. Marine and Freshwater Research: Online early DOI 10.1071/MF15246.

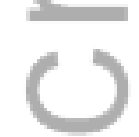

Ladson AR, White LJ, Doolan JA, Finlayson BL, Hart BT, Lake PS, Tilleard JW. 1999. Development and testing of an Index of Stream Condition for waterway management in Australia. Freshwater Biology 41: 453-468.

Lintemans M. 2007. 'Fishes of the Murray-Darling Basin: an introductory guide.' (Murray-Darling Basin Commission: Canberra).

Máčka Z, Krejčí L, Loučková B, Peterková L. 2011. A critical review of field techniques employed in the survey of large woody debris in river corridors: a central European perspective. Environmental Monitoring and Assessment 181: 291-316.

Maddock I. 1999. The importance of physical habitat assessment for evaluating river health. Freshwater Biology 41: 373-391. 
Mao L, Andreoli A, Comiti F, Lenzi MA. 2008. Geomorphic effects of large wood jams on a sub-antarctic mountain stream. River Research and Applications 24: 249266.

Marcus WA, Marston RA, Colvard Jr CR, Gray RD. 2002. Mapping the spatial and temporal distributions of woody debris in streams of the Greater Yellowstone Ecosystem, USA. Geomorphology 44: 323-335.

Marcus WA, Fonstad MA. 2008. Optical remote mapping of rivers at sub-meter resolutions and watershed extents. Earth Surface Processes and Landforms 33: 4-24.

Morrongiello J R, Crook DA, King AJ, Ramsey DSL, Brown P. 2011. Impacts of drought and predicted effects of climate change on fish growth in temperate Australian lakes. Global Change Biology 17: 745-755.

Mosley MP. 1981. The influence of organic debris on channel morphology and bedload transport in a New Zealand forest stream. Earth Surface Processes and Landforms 6(6): 571-579.

Nicol SJ, Lieschke JA, Lyon JP, Koehn JD. 2004. Observations on the distribution and abundance of carp and native fish, and their responses to a habitat restoration trial in the Murray River, Australia. New Zealand Journal of Marine and Freshwater Research 38: 541-551. 
Ormerod S. 2004. Editorial: A golden age of river restoration science. Aquatic Conservation 14: 543-549.

Pesonen A, Maltamo M, Eerikäinen K, Packalèn P. 2008. Aerial laser scanning-based prediction of coarse woody debris volumes in a conservation area. Forest Ecology and Management 255: 3288-3296.

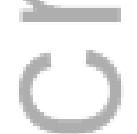

R Development Core Team. 2013. R: A Language and Environment for Statistical Computing. R Foundation for Statistical Computing:Vienna, Austria.. Retrieved from http://www.R-project.org

Robson, B. 2008. Managing flows for ephemeral streams (Fact sheet 2). Land and Water Australia, Australian Government: Canberra, Australia.

Rosenfeld JS, Huato L. 2003. Relationship between large woody debris characteristics and pool formation in small coastal British Columbia streams. North American Journal of Fisheries Management 23: 928-938.

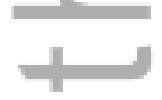

VRHS. 2002. Healthy rivers, healthy communities and regional growth: Victorian River Health Strategy. Department of Natural Resources and Environment: Victoria, Australia. 
Wallace JB, Webster JR, Meyer JL. 1995. Influence of log additions on physical and biotic characteristics of a mountain stream. Canadian Journal of Fisheries and Aquatic Sciences 52: 2120-2137.

Wilson, P. 2013. Index of Stream Condition: The third benchmark of Victorian river condition. Department of Environment and Primary Industries: East Melbourne,

Victoria, Australia

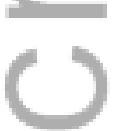

Wohl E, Cenderelli DA, Dwire KA, Ryan-Burkett SE, Young MK, Fausch KD. 2010.

Large in-stream wood studies: a call for common metrics. Earth Surface Processes and Landforms 35: 618-625.

Young MK. 1994. Movement and characteristics of stream-borne course woody debris in adjacent burned and undisturbed water-sheds in Wyoming. Canadian Journal of Forest Research 24: 1933-1938.

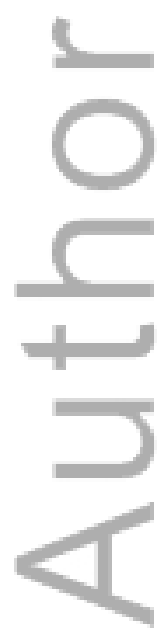


Table 1. Footprint size $\left(\mathrm{m}^{2}\right)$, complexity score and estimated volumes $\left(\mathrm{m}^{3}\right)$ for each of the 16 Instream Woody Habitat (IWH) mass categories. Table reproduced from Kitchingman et al., (2015).

\begin{tabular}{llll}
\hline $\begin{array}{l}\text { IWH } \\
\text { category }\end{array}$ & $\begin{array}{l}\text { Footprint size } \\
\left(\mathbf{m}^{2}\right)\end{array}$ & $\begin{array}{l}\text { Complexity category } \\
\text { (no. stems) }\end{array}$ & $\begin{array}{l}\text { Mean } \\
\left.\text { volume } \mathbf{( m}^{\mathbf{3}}\right)\end{array}$ \\
\hline 1_1 & $1-5$ & 1 & 1.10 \\
1 2 & $1-5$ & 2 & 0.63 \\
1 1_3 & $1-5$ & 3 & 0.70 \\
1_4 & $1-5$ & $\geq 4$ & 0.94 \\
2_1 & $>5-10$ & 1 & 3.67 \\
2_2 & $>5-10$ & 2 & 1.06 \\
2_3 & $>5-10$ & 3 & 0.56 \\
2_4 & $>5-10$ & $\geq 4$ & 1.20 \\
3_1 & $>10-20$ & 1 & 8.12 \\
3_2 & $>10-20$ & 2 & 1.86 \\
3_3 & $>10-20$ & 3 & 1.53 \\
3_4 & $>10-20$ & $\geq 4$ & 2.38 \\
4_1 & $>20$ & 1 & 18.18 \\
4_2 & $>20$ & 2 & 7.44 \\
4_3 & $>20$ & 3 & 7.57 \\
4_4 & $>20$ & $\geq 4$ & 14.62 \\
\hline
\end{tabular}




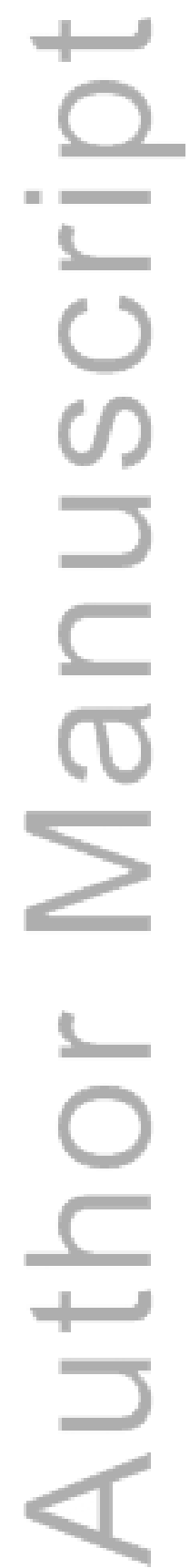

This article is protected by copyright. All rights reserved. 
Table 2. Results of model selection procedure for 19 combinations of instream woody habitat (IWH) volume predictors. Predictors were aerial_vol = aerial standardised IWH volume $\left(\mathrm{m}^{3} \mathrm{~m}^{-2}\right)$ for stream link; mean_bw = average toe-of-bank channel width for stream link; veg_over = proportion of stream link area covered by overhanging vegetation. AICc Akaike's Information Criterion corrected for small sample size; $\triangle \mathrm{AICc}$, difference in AICc between this model and the model with the lowest AICc.

\begin{tabular}{|c|c|c|c|c|}
\hline Model No. & Model & Log_Likelyhood & AICc & $\Delta \mathrm{AICc}$ \\
\hline 1 & aerial_vol + mean_bw + veg_over + aerial_vol : mean_bw + aerial_vol : veg_over & 6 & 942.625 & 0 \\
\hline $2=$ & aerial_vol + mean_bw + veg_over + aerial_vol : mean_bw + mean_bw : veg_over & 6 & 942.1845 & 0.881114196 \\
\hline 3 & aerial_vol + mean_bw + aerial_vol : mean_bw + mean_bw : veg_over & 5 & 940.8948 & 1.417735193 \\
\hline 4 & aerial_vol + mean_bw + veg_over + aerial_vol : mean_bw + aerial_vol : veg_over + mean_bw : veg_over & 7 & 942.873 & 1.553957037 \\
\hline 5 & aerial_vol + mean_bw + veg_over + aerial_vol : mean_bw + aerial_vol : veg_over + aerial_vol : mean_bw : veg_over & 7 & 942.7949 & 1.710296563 \\
\hline & $\begin{array}{l}\text { aerial_vol + mean_bw + veg_over + aerial_vol : mean_bw + aerial_vol : veg_over + mean_bw : veg_over + aerial_vol } \\
\text { : mean_bw : veg_over }\end{array}$ & 9 & 944.7445 & 1.933014413 \\
\hline 7 & aerial_vol + mean_bw + aerial_vol : mean_bw & 4 & 939.3129 & 2.546022669 \\
\hline 8 & aerial_vol + mean_bw + veg_over + aerial : mean_bw & 5 & 940.2606 & 2.686115539 \\
\hline 9 & aerial_vol + mean_bw + veg_over + aerial_vol : mean_bw + mean_bw : veg_over + aerial_vol : mean_bw : veg_over & 7 & 942.2492 & 2.801580829 \\
\hline & $\begin{array}{l}\text { aerial_vol + mean_bw + veg_over + aerial_vol : mean_bw + aerial_vol : veg_over + mean_bw:veg_over + aerial_vol : } \\
\text { mean_bw : veg_over }\end{array}$ & 8 & 943.0264 & 3.304501198 \\
\hline 11 & aerial_vol + mean_bw + veg_over+aerial_vol : mean_bw + aerial_vol : mean_bw:veg_over & 6 & 940.2794 & 4.691276226 \\
\hline 12 & aerial_vol + aerial_vol : mean_bw & 3 & 886.974 & 105.1954903 \\
\hline 13 & aerial_vol + veg_over + aerial_vol : mean_bw & 4 & 886.9817 & 107.2084326 \\
\hline 14 & aerial_vol + veg_over + aerial_vol : mean_bw + aerial_vol : mean_bw : veg_over & 5 & 887.5852 & 108.036928 \\
\hline $15^{-1}$ & aerial_vol + mean_bw + veg_over & 4 & 855.1607 & 170.8504286 \\
\hline 16 & aerial_vol + mean_bw + veg_over + aerial_vol : veg_over & 5 & 855.4794 & 172.2485121 \\
\hline 17 & aerial_vol + mean_bw & 3 & 830.5078 & 218.1277722 \\
\hline 18 & aerial_vol + veg_over & 3 & 813.5829 & 251.9776655 \\
\hline 19 & aerial_vol & 2 & 782.7344 & 311.6533704 \\
\hline
\end{tabular}




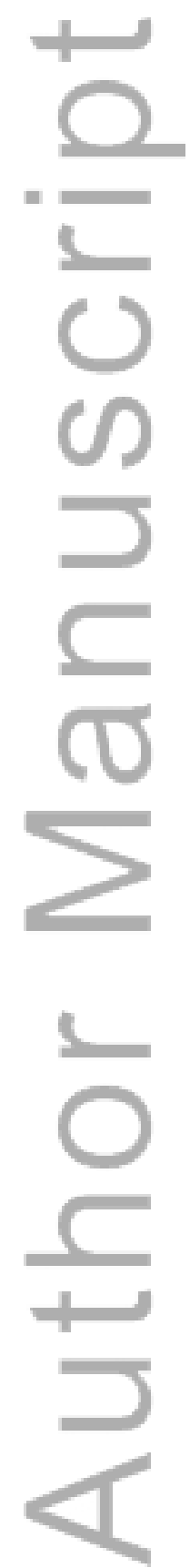

This article is protected by copyright. All rights reserved. 
Table 3. Instream woody habitat volumes (average $\pm \mathrm{se} ; \mathrm{m}^{3} \mathrm{~m}^{-2}$ ) as predicted under reference (from Kitchingman et al., 2015) and current conditions for each of Victoria's river regions. Average differences in volume and median percentage change values (condition value) between reference and current volumes also presented.

\begin{tabular}{|c|c|c|c|c|c|c|c|c|c|}
\hline & RIVER REGION & Reference volume & se & Current volume & se & Change & se & $\%$ change & se \\
\hline & Alps & 0.0192 & 0.0002 & 0.0165 & 0.0005 & -0.0027 & 0.0005 & -36.5 & 2.7 \\
\hline East Gippsland & east of the Snowy River - lowlands & 0.0304 & 0.0005 & 0.0145 & 0.0003 & -0.0159 & 0.0005 & -51.6 & 2.0 \\
\hline \multicolumn{2}{|c|}{ East Gippsland east of the Snowy River - uplands } & 0.0223 & 0.0003 & 0.0159 & 0.0003 & -0.0064 & 0.0004 & -23.4 & 1.8 \\
\hline & Glenelg catchment & 0.0585 & 0.0002 & 0.0095 & 0.0003 & -0.0490 & 0.0004 & -85.9 & 0.4 \\
\hline & Grampians & 0.0661 & 0.0006 & 0.0235 & 0.0016 & -0.0426 & 0.0017 & -76.3 & 2.4 \\
\hline & North central floodplains & 0.0482 & 0.0004 & 0.0102 & 0.0002 & -0.0380 & 0.0004 & -79.9 & 0.4 \\
\hline & North central midlands & 0.0319 & 0.0003 & 0.0132 & 0.0002 & -0.0187 & 0.0003 & -61.2 & 1.1 \\
\hline & North central uplands & 0.0206 & 0.0002 & 0.0124 & 0.0003 & -0.0082 & 0.0003 & -46.0 & 1.9 \\
\hline & North east floodplains & 0.0173 & 0.0004 & 0.0118 & 0.0004 & -0.0055 & 0.0005 & -36.4 & 23.8 \\
\hline \multirow{4}{*}{$\longrightarrow$} & North east uplands & 0.0141 & 0.0002 & 0.0113 & 0.0002 & -0.0028 & 0.0002 & -20.0 & 11.7 \\
\hline & North west floodplains & 0.0561 & 0.0002 & 0.0180 & 0.0004 & -0.0381 & 0.0004 & -72.1 & 0.6 \\
\hline & North west uplands & 0.0457 & 0.0003 & 0.0138 & 0.0002 & -0.0319 & 0.0004 & -72.5 & 0.7 \\
\hline & Otway Ranges & 0.0328 & 0.0005 & 0.0176 & 0.0004 & -0.0152 & 0.0005 & -46.4 & 1.3 \\
\hline \multirow{4}{*}{1} & South central & 0.0456 & 0.0003 & 0.0112 & 0.0002 & -0.0344 & 0.0004 & -80.4 & 0.7 \\
\hline & South central lowlands & 0.0396 & 0.0004 & 0.0185 & 0.0005 & -0.0211 & 0.0007 & -55.0 & 1.5 \\
\hline & South central uplands & 0.0284 & 0.0003 & 0.0194 & 0.0003 & -0.0090 & 0.0003 & -30.7 & 1.1 \\
\hline & South east floodplains & 0.0322 & 0.0002 & 0.0115 & 0.0002 & -0.0207 & 0.0003 & -69.6 & 0.7 \\
\hline & South east slopes & 0.0171 & 0.0001 & 0.0089 & 0.0001 & -0.0083 & 0.0001 & -56.0 & 2.4 \\
\hline & South west floodplains & 0.0576 & 0.0003 & 0.0055 & 0.0002 & -0.0522 & 0.0004 & -95.1 & 0.3 \\
\hline
\end{tabular}




\begin{tabular}{|c|c|c|c|c|c|c|c|c|c|}
\hline & Strezleckis & 0.0242 & 0.0005 & 0.0139 & 0.0003 & -0.0103 & 0.0006 & -40.0 & 2.3 \\
\hline & Wilsons Promontory & 0.0350 & 0.0017 & 0.0166 & 0.0016 & -0.0184 & 0.0025 & -48.3 & 6.0 \\
\hline 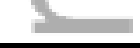 & AVERAGE & 0.0336 & 0.0001 & 0.0128 & 0.0001 & -0.0207 & 0.0001 & -41.0 & 1.0 \\
\hline
\end{tabular}




\section{Figure captions}

Figure 1. The location of on-ground assessments of instream woody habitat (black x's) relative to the riverine biological regions (VRHS 2002) in Victoria, Australia. Numbers correspond to different riverine biological regions, as named in the insert box. Figure modified from Kitchingman et al., (2015) to include additional sites.

Figure 2. Example of an aerial image displaying identified instream woody habitat (IWH) masses on the Ovens River. Size (S) and complexity (C) scores included for several masses.

Figure 3. Scatterplot of raw differences (and Loess smoother line of fit) between measures of instream woody habitat volumes $\left(\mathrm{m}^{3} \mathrm{~m}^{-2}\right)$ between groundtruthed sites and aerial data for 477 stream links across Victoria. Values $>0$ indicate underestimation of aerial measures.

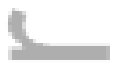

Figure 4. Predicted current instream woody habitat volumes (average $\mathrm{m}^{3} \mathrm{~m}^{-2}$ ) across 38,988 stream links of Victoria. Riverine biological region boundaries also included.

Figure 5. Predicted current condition of IWH as indicated by the $\%$ change from predicted reference levels (as reported in Kitchingman et al., 2015) across 38,988 stream links of Victoria. Riverine biological regions and detailed insert highlight variation of IWH condition across and within regions and rivers. 


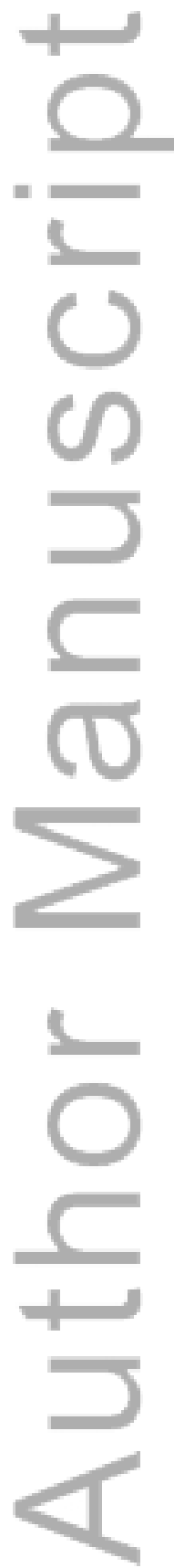

This article is protected by copyright. All rights reserved. 


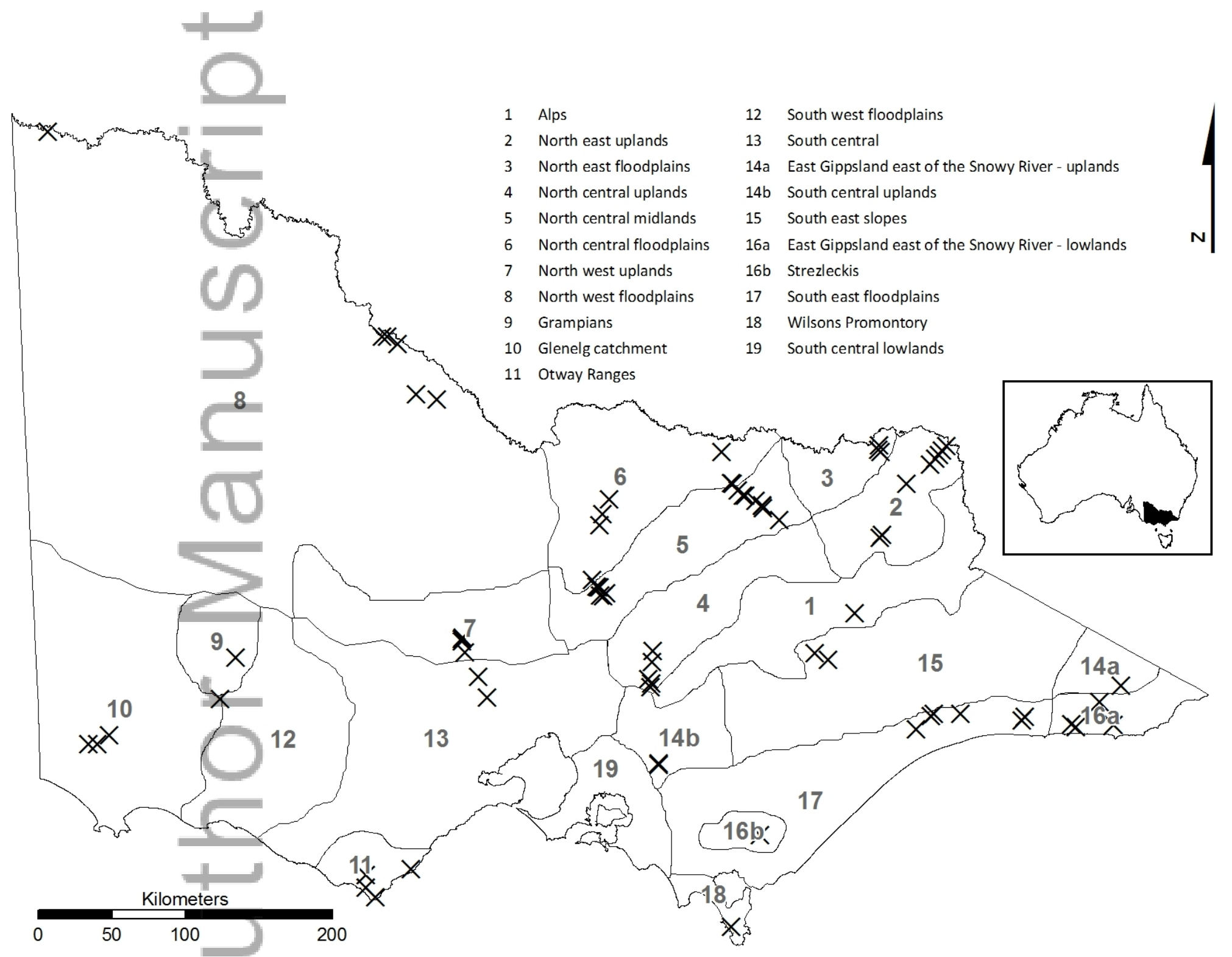

RRA_3002_F1.jpg 


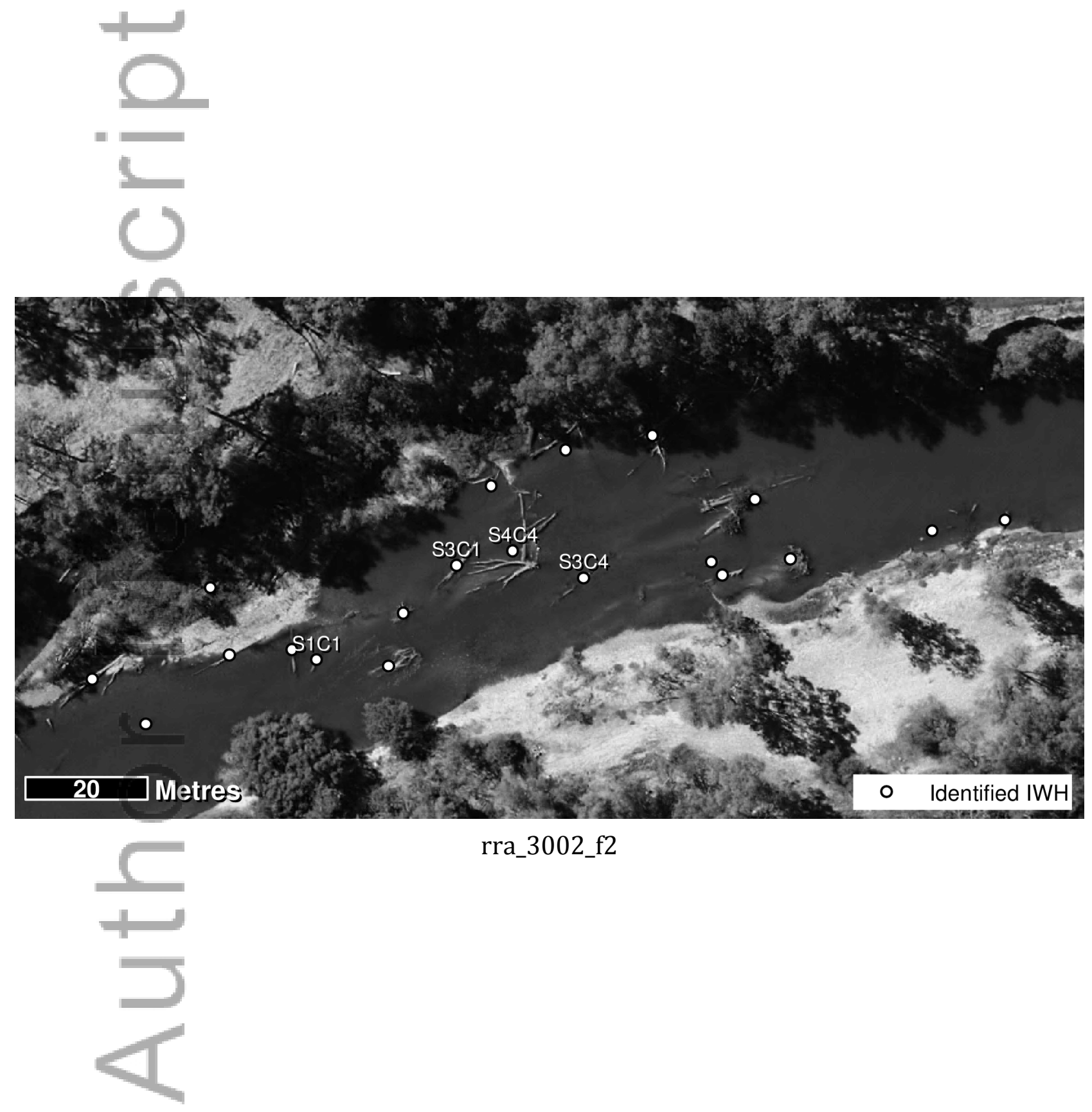

This article is protected by copyright. All rights reserved. 

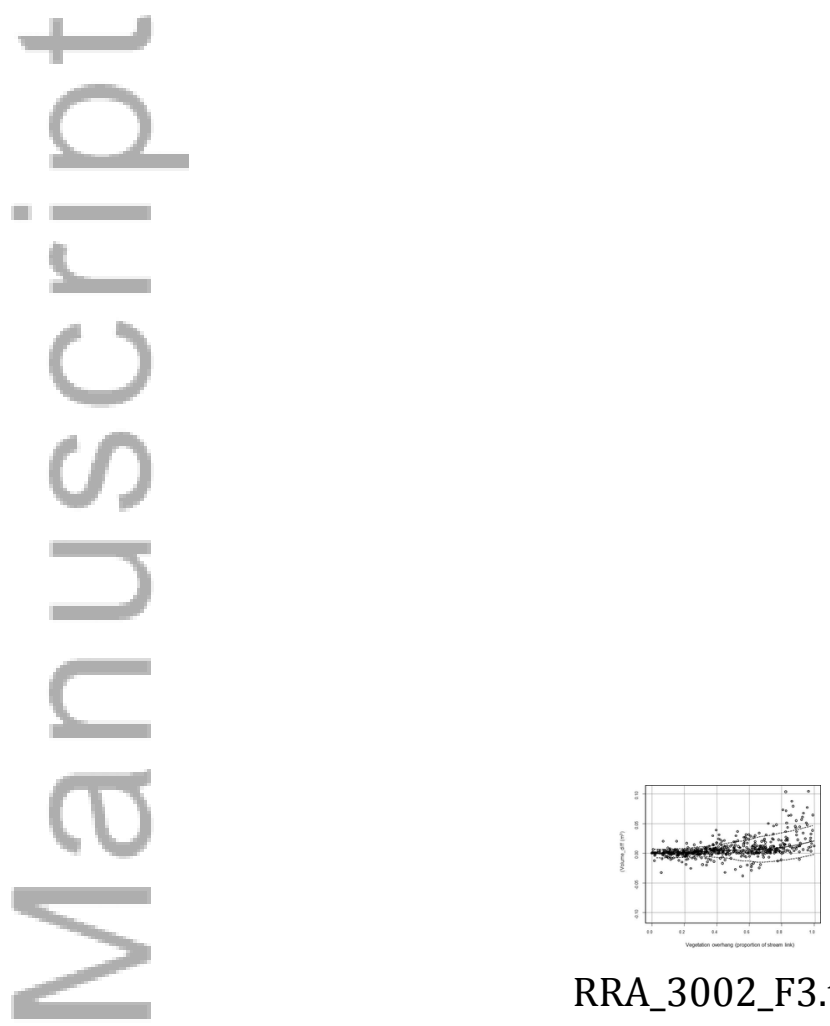

RRA_3002_F3.tif

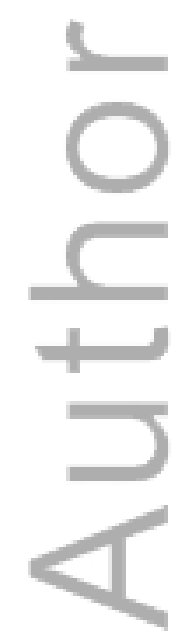

This article is protected by copyright. All rights reserved. 


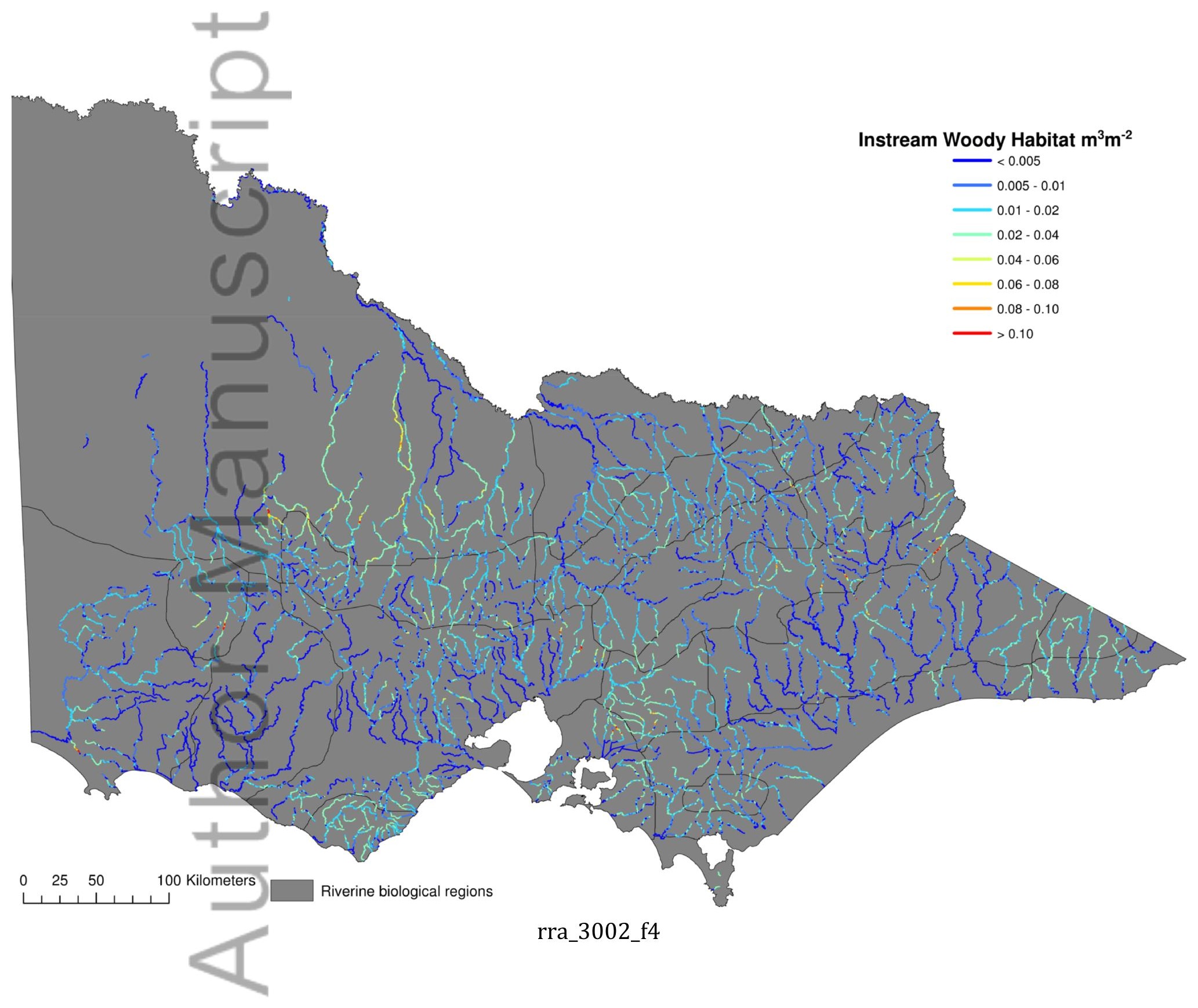

This article is protected by copyright. All rights reserved. 


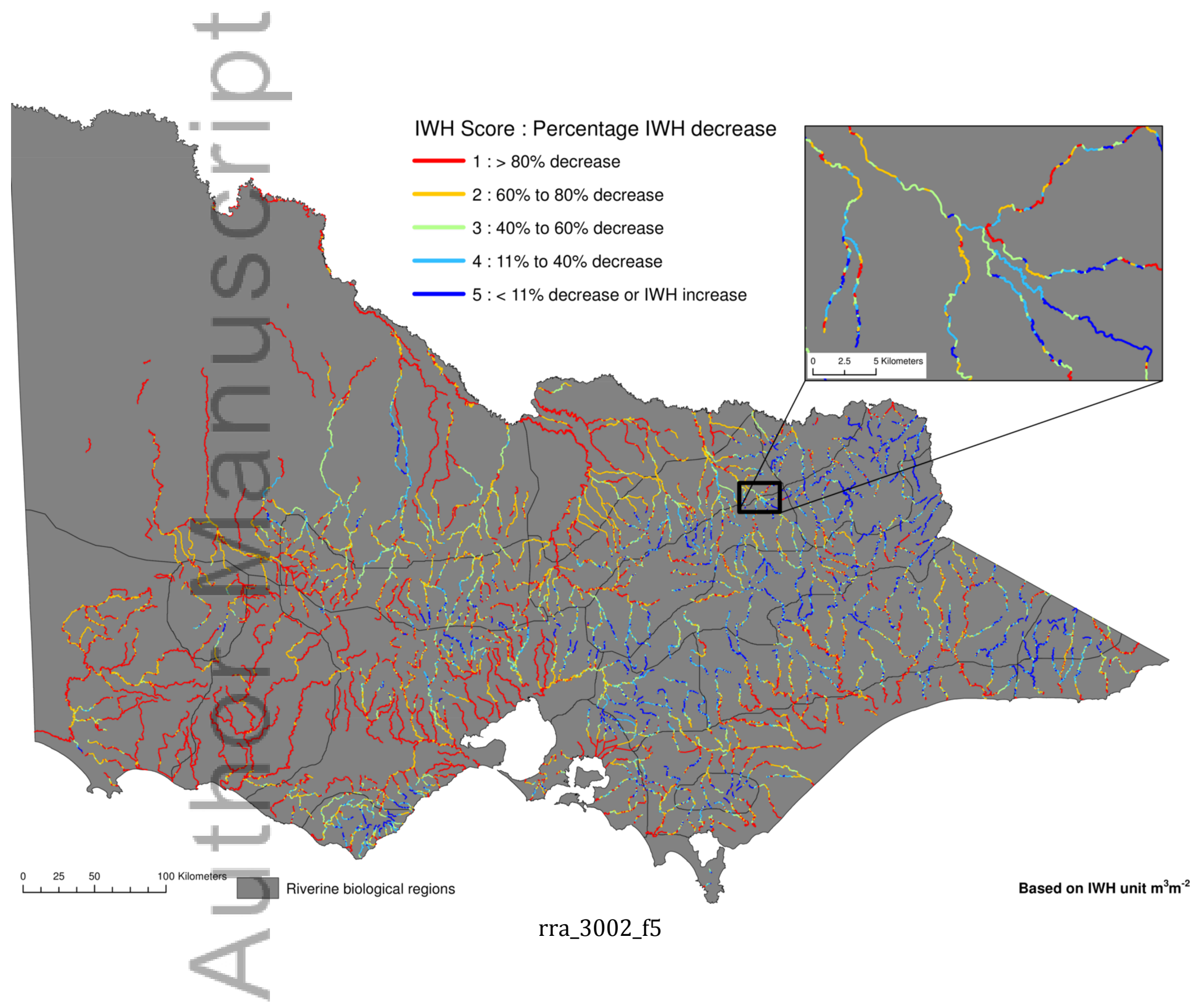

This article is protected by copyright. All rights reserved. 


\section{University Library}

\section{- M M N E R VA A gateway to Melbourne's research publications}

Minerva Access is the Institutional Repository of The University of Melbourne

\section{Author/s:}

Tonkin, Z;Kitchingman, A;Ayres, RM;Lyon, J;Rutherfurd, ID;Stout, JC;Wilson, P

Title:

Assessing the Distribution and Changes of Instream Woody Habitat in South-Eastern Australian Rivers

\section{Date:}

2016-09-01

\section{Citation:}

Tonkin, Z., Kitchingman, A., Ayres, R. M., Lyon, J., Rutherfurd, I. D., Stout, J. C. \& Wilson, P. (2016). Assessing the Distribution and Changes of Instream Woody Habitat in South-Eastern Australian Rivers. RIVER RESEARCH AND APPLICATIONS, 32 (7), pp.1576-1586. https:// doi.org/10.1002/rra.3002.

Persistent Link:

http://hdl.handle.net/11343/291001 